\title{
Експериментальні дослідження фрагмента попередньо напруженої захисної оболонки енергоблока атомної станції
}

- Бамбура Андрій Миколайович, д-р техн. наук, проф.

Державне підприємство «Державний науково-дослідний інститут будівельних конструкцій», м. Київ, Україна

ORCID: https://orcid.org/0000-0003-1402-3345

- Сазонова Ірина Ростиславівна

Державне підприємство «Державний науково-дослідний інститут будівельних конструкцій», м. Київ, Україна

ORCID: https://orcid.org/0000-0002-8226-3589

- Карпенко Олександр Анатолійович

Державне підприємство «Державний науково-дослідний інститут будівельних конструкцій», м. Київ, Україна

ORCID: https://orcid.org/0000-0002-7943-1537

- Жарко Людмила Олексіївна, канд. техн. наук, доц.

Державне підприємство «Державний науково-дослідний інститут будівельних конструкцій», м. Київ, Україна

ORCID: https://orcid.org/0000-0002-5966-1060

— Фесенко Олег Анатолійович, канд. техн. наук

Державне підприємство «Державний науково-дослідний інститут будівельних конструкцій», м. Київ, Україна

ORCID: https://orcid.org/0000-0001-8154-2239

- Інюшев Владислав Валерійович, канд. техн. наук

Державне підприємство «Державний науково-інженерний центр систем контролю та аварійного реагування», м. Київ, Україна ORCID: https://orcid.org/0000-0002-1040-950X

- Жигалов Ян Анатолійович

Державне підприємство «Державний науково-інженерний центр систем контролю та аварійного реагування», м. Київ, Україна ORCID: https://orcid.org/0000-0002-2080-7122

- Посох Валерій Олегович

Державне підприємство «Державний науково-інженерний центр систем контролю та аварійного реагування», м. Київ, Україна

ORCID: https://orcid.org/0000-0002-6911-7237

Захисна оболонка є елементом системи захисту реакторної установки, що ізолює їі від навколишнього середовища та забезпечує локалізацію радіоактивних речовин у підоболонковому просторі в разі потенційно можливих проєктних аварій. Для забезпечення герметичності реакторного відділення по внутрішній залізобетонній поверхні захисної оболонки влаштовано герметизуюче сталеве облицювання товщиною 8 мм. 
Відповідно до чинних будівельних норм під час розрахунків конструкцій захисних оболонок потрібно виконувати перевірку герметизуючого сталевого облицювання на втрату стійкості. Перевірка елементів сталевого облицювання на втрату стійкості за методом, наведеним у ПНАЭ [-10-007-89 [1], показала, що під час дії максимальної проєктної аварії відбувається втрата стійкості герметизуючого сталевого облицювання, що унеможливлює продовження ресурсу реактора. Для вивчення цього питання була розроблена програма експериментальних досліджень збереження цілісності герметизуючого сталевого облицювання (зокрема зварних швів) у разі можливої втрати стійкості облицювання внаслідок заданих силових та температурних впливів. Метою експериментальних досліджень було вивчення напружено-деформованого стану фізично і геометрично обгрунтованих моделей захисної оболонки атомних станцій щодо збереження цілісності герметизуючого сталевого облицювання (зокрема зварних швів) у разі втрати стійкості облицювання під впливом навантажень, які виникають під час максимальної проєктної аварії. У процесі підготовки експериментальних досліджень були розроблені технічні рішення дослідних зразків (моделей) та устаткування для випробувань. Під час розробки дослідних моделей були використані результати обстежень технічного стану захисної оболонки, дані щодо реальної міцності та складу бетону. За результатами проведених випробувань трьох дослідних зразків захисної оболонки енергоблоків було встановлено, що втрати стійкості сталевої оболонки дослідних зразків не відбулося, відповідно, не було зафіксовано руйнувань, пошкоджень, порушення герметичності дослідних зразків.

Ключові слова: втрата стійкості, герметизуюче сталеве облицювання, дослідні зразки, захисна оболонка, проєктна аварія, стенд для випробувань, технічний стан.

(с) Бамбура А. М., Сазонова І. Р., Карпенко О. А., Жарко Л. О., Фесенко О. А., Інюшев В. В., Жигалов Я. А., Посох В. О., 2021

\section{Постановка проблеми}

Більшість енергоблоків атомних електростанцій України працюють вже понад 30 років. Тому, питання подовження строку їх експлуатації $\epsilon$ надзвичайно актуальним.

Відповідно до чинної нормативної бази України під час визначення залишкового ресурсу будівельних об'єктів необхідно виконати візуальні та інструментальні обстеження і розрахунки на всі види навантажень та впливів з урахуванням результатів обстежень. У межах робіт з подовження строку експлуатації атомних електростанцій було виконано моделювання та оцінку напружено-деформованого стану низки захисних оболонок реакторного відділення (РВ) енергоблоків на всі необхідні сполучення навантажень.

Захисна оболонка $є$ елементом системи захисту реакторної установки, яка ізолює її від навколишнього середовища та забезпечує локалізацію радіоактивних речовин у підоболонковому просторі в разі потенційно можливих проєктних аварій. За своєю конфігурацією захисна оболонка $є$ попередньо напруженою залізобетонною конструкцією у вигляді циліндра з товщиною стінки 1200 мм. Внутрішній радіус циліндра 45 м. Верхня частина циліндра сполучається 3 похилим сферичним куполом товщиною 1100 мм. Нижня частина циліндра спирається на залізобетонну плиту перекриття (нижню плиту захисної оболонки).

Для забезпечення герметичності РВ по внутрішній поверхні захисної оболонки (ії залізобетонної частини) влаштовано герметизуюче сталеве облицювання (ГСО) товщиною 8 мм з вуглецевої сталі марки ВстЗсп5.

Відповідно до національних будівельних норм під час розрахунків конструкцій захисних оболонок необхідно виконувати перевірку ГСО на втрату стійкості. Перевірка елементів сталевого облицювання на втрату стійкості за методом ПНАЭ Г-10-007-89 [1] показала, що під час дії максимальної проєктної аварії (МПА) відбувається втрата стійкості ГСО, що унеможливлює продовження строку експлуатації реактора. Будь-якого експериментального підтвердження вказаної методики розрахунку з відомих джерел нами не встановлено. Аналіз методики розрахунку втрати стійкості сталевого облицювання показав, що вона не враховує такі важливі фактори як адгезію металу 3 бетоном, наявність тиску на зовнішню поверхню листа. У разі втрати стійкості металевої оболонки (мембрани) ці фактори мають значний вплив. Причому, втрата стійкості може виникнути тільки на лінійній стадії, оскільки деформації металу складають менше $120 \times 10^{-5}$ відносних одиниць. Для вивчення цього питання була розроблена програма експериментальних досліджень збереження цілісності ГСО (зокрема зварних швів) у разі втрати стійкості облицювання внаслідок заданих силових та температурних впливів.

Наявні дані 3 науково-технічної літератури, присвяченої експериментальним дослідженням 3 визначення локалізуючої здатності захисних оболонок атомних станцій, дуже обмежені. Найбільш повними і максимально наближеними 
до особливостей роботи реальних захисних оболонок атомних станцій $\epsilon$ експериментальні дослідження, виконані в кооперації 7 країн (8 фірм). Роботи виконувалися згідно з рішенням від червня 2002 року Комітету з безпеки ядерних установок (CSNI), який ініціював дослідження Міжнародної стандартної задачі на цілісність захисної оболонки (ISP 48) на основі тесту CPH / NUPEC / Sandia [2]. Метою ISP було вивчення напружено-деформованого стану реальних конструкцій захисних оболонок 3 попередньо напруженого бетону на основі результатів натурного випробування [2].

У межах цих досліджень була розроблена програма з метою вивчення реакції представницьких моделей захисної оболонки, розроблених різними фірмами, на впливи під час проєктної аварії та порівняння аналітичних прогнозів і результатів натурного випробування. Експериментальна модель масштабом 1:4 становила попередньо напружену залізобетонну захисну оболонку водно-водяного реактора (PWR) блока № 3 атомної станції Охі в Японії.

3 огляду на зазначене вище, експериментальні дослідження поведінки ГСО під час проєктних аварій $є$ дуже актуальними та своєчасними.

\section{Мета досліджень}

Метою експериментальних досліджень було вивчення напружено-деформованого стану фізично і геометрично обгрунтованих моделей захисної оболонки атомних станцій щодо збереження цілісності ГСО (зокрема зварних швів) у разі втрати стійкості облицювання під впливом навантажень, які виникають під час МПА.

\section{Основний матеріал}

До початку проведення експерименту була розроблена Робоча програма досліджень, яка пройшла державну експертизу ядерної та радіаційної безпеки в Державному підприємстві «Державний науково-технічний центр 3 ядерної та радіаційної безпеки (ДНТЦ ЯРБ), погоджена Державною інспекцією ядерного регулювання України (Держатомрегулювання) і затверджена Державним підприємством «Національна атомна енергогенеруюча компанія «Енергоатом» [3].

Виготовлення дослідних зразків, підготовка, виконання та результати експериментальних досліджень у повному обсязі наведені в документі [4], який також пройшов державну експертизу ядерної та радіаційної безпеки в ДНТЦ ЯРБ. Результати експериментальних досліджень [4] рекомендовані Держатомрегулюванням для обгрун- тування безпечної довгострокової експлуатації енергоблоків №№ 1, 2 Відокремленого підрозділу «Южно-українська атомна електрична станція».

Експериментальні дослідження [4] зразків, які моделюють фрагменти захисної оболонки, складались 3 таких етапів: розробка технічних рішень експериментальних зразків (моделей); розробка технічних рішень устаткування для проведення випробувань; виготовлення експериментальних зразків (моделей) захисної оболонки; виготовлення устаткування (стенда) для проведення випробувань; підготовка експериментальних зразків (моделей) та устаткування; проведення випробувань; аналіз результатів випробувань.

\section{Розробка технічних рішень експеримен- тальних зразків}

Розміри моделі (фрагмента захисної оболонки) були зумовлені технічними можливостями щодо виготовлення експериментальних зразків, умовами їх транспортування та забезпечення програми випробувань. Так, наприклад, необхідно було забезпечити герметичність контакту між дослідним зразком і стендом при тиску в камері 0,35 МПа. За прийнятих розмірів зразка мінімальне зусилля, яке повинно було сприйняти устаткування, складало 3,024 МН (біля 300 тс) і це без урахування достатнього для обтиску контакту зусилля. Для мінімальної статистичної забезпеченості передбачено виготовлення трьох моделей ГСО у такий спосіб, аби граничні умови по периметру фрагмента практично не впливали на напружено-деформований стан і вичерпання несучої здатності досліджуваних моделей ГСО. Зважаючи на це, модель зразка складалася 3 тридцяти шести пластин (листів) розміром $40 \mathrm{~cm} \times 60 \mathrm{~cm}$ товщиною 8 мм (розміри дослідних зразків 3600 мм × 2400 мм × 300 мм). Розміри і товщина листів ГСО відповідали їх натуральним розмірам. Сталеві листи ГСО виготовлені із товстолистової сталі СТ3. Висота відповідає відстані між анкерними стрижнями кріплення, а ширина - приблизній відстані між вертикальними елементами просторових ферм (кутики 50 мм $\times 5$ мм). Для бетонування зразків був застосований бетон класу С32/40, найбільш близький за складом до використаного під час зведення енергоблоків.

У процесі визначення оптимальної кількості пластин на один зразок виходили з необхідності дослідження поведінки елементів пластин 3 граничними умовами, ідентичними експлуатаційним. Крайні ряди пластин у поперечному напрямку кріпилися суцільним швом зварювання до жорсткої рами з прокатних профілів за допомогою кутиків 50 ммх5 мм. На внутрішніх гранях 
пластини в поперечному напрямку приварювалися до кутиків 50 мм × 5 мм (поз. 3 на Рисунку 1). У поздовжньому напрямку пластини між собою також з'єднуються зварними рівноміцними швами. Водночас була забезпечена герметичність ГСО, яка перевірялася кольоровим капілярним способом. На контрольовану поверхню з одного боку був нанесений шар індикаторного покриття (проявник), після його висихання з протилежного боку наносять контрольну рідину (пенетрант). Контрольна рідина під дією капілярних сил проникає крізь наскрізні дефекти мембрани і, стикаючись з індикаторним покриттям, утворює на ньому контрастні плями. Наявність та розташування плям показують, чи $є$ наскрізні дефекти і де вони розташовані [5].

Для коректної оцінки напружено-деформованого стану і можливої втрати стійкості (випинання листів моделі ГСО всередину) задана кривизна моделі, рівна внутрішній кривизні захисної оболонки.

В експерименті обтиснення бетону попередньо напруженими канатами моделюється за допомогою попередньо напружених арматурних стрижнів діаметром 32 мм класу А500С (поз. 5 на Рисунку 1). Стрижні пропускаються через каналоутворювачі діаметром 40 мм (поз. 8 на Рисунку 1). Конструкція дослідного зразка зображена на Рисунку 1.
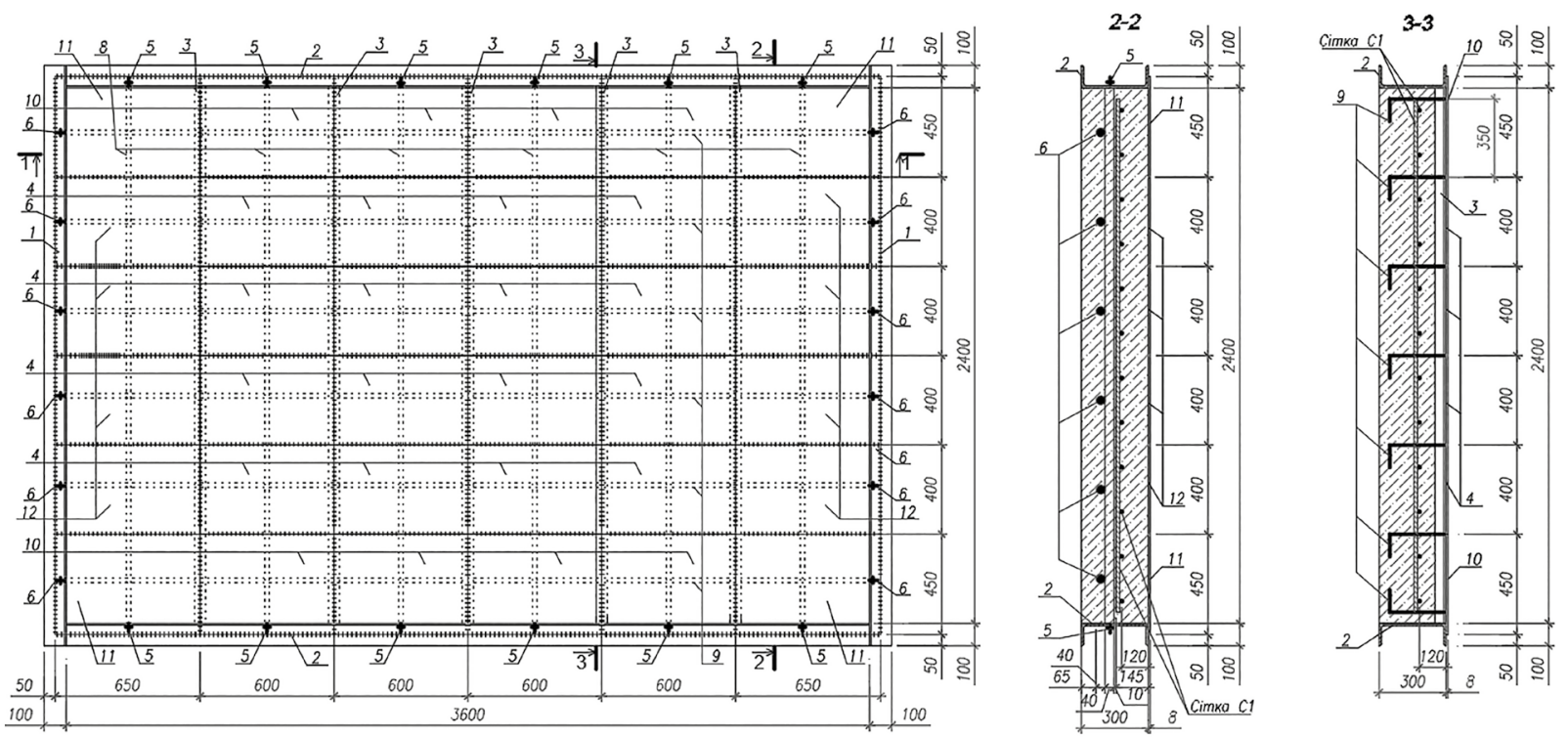

$1-1$
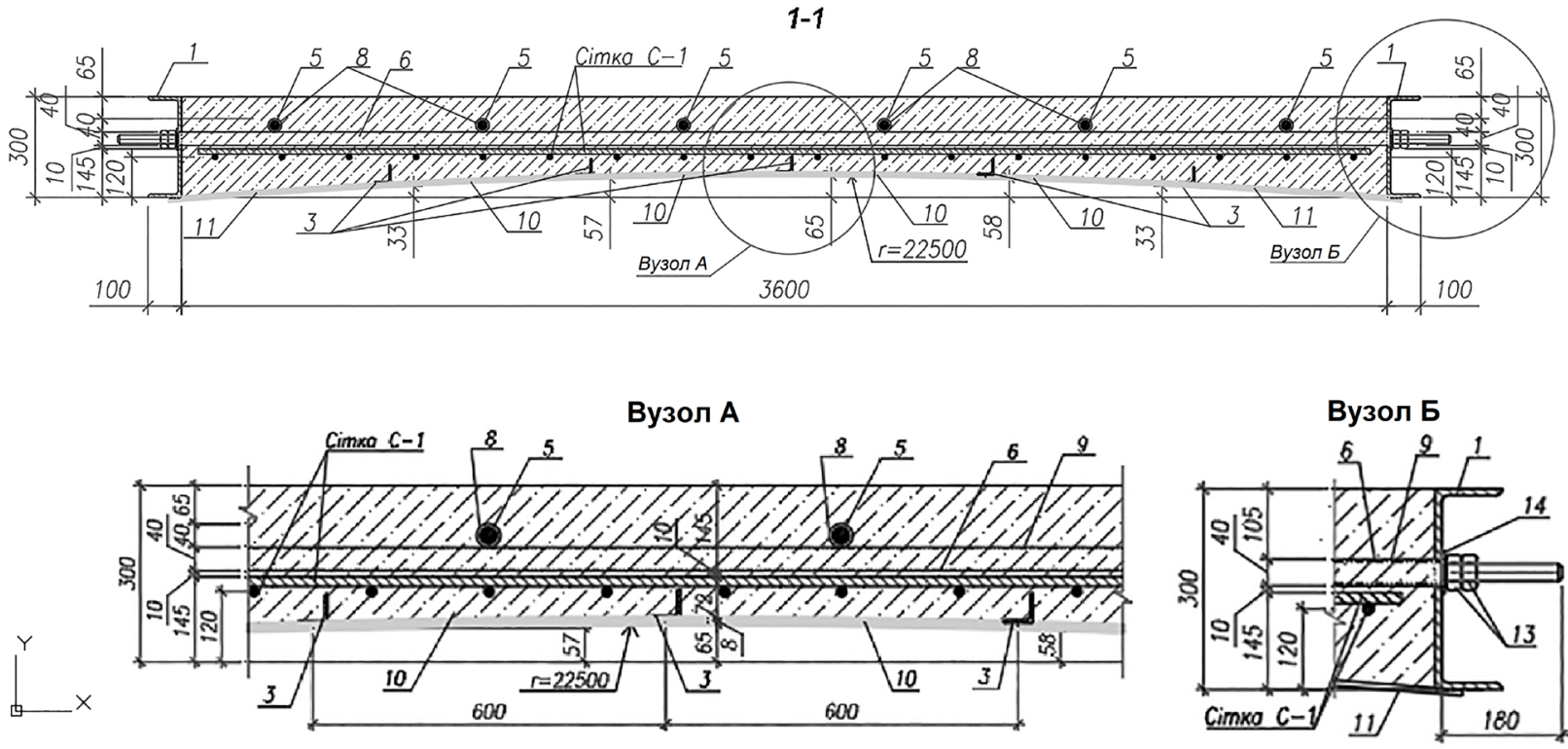

Примітки:

1, 2 - швелери [ 30; 3 - кутики L 50 мм $\times 5$ мм; 4 - сталевий лист 600 мм $\times 400$ мм $\times 8$ мм; 5, 6 - передньо напружені стрижні $\varnothing 32$ мм; 7 - стрижні $\varnothing 12$ мм; 8, 9 - труба ПВХ $\varnothing 40$ мм; 10, 11, 12 - сталеві листи; 13 - гайка; 14 - шайба

Рисунок 1 - Конструкція дослідного зразка для дослідження стійкості ГСО та зварних швів 


\section{Технічні рішення устаткування для проведення випробувань}

Стенд для випробування дослідних зразків захисної оболонки - це залізобетонна плита товщиною 100 мм, облямована по контуру швелерами [ 22. До рами зі швелерів (по середині висоти) приварюються листи товщиною 2 мм. Для підтримки температури поверхні сталевих листів дослідного зразка не нижче $100{ }^{\circ} \mathrm{C}$ випробувальний стенд обладнаний системою підігріву з труб, по яких під час випробувань під тиском подається пара. Зверху труб розташовується арматурна сітка зі стрижнів $\varnothing 12$ з розмірами осередку 150 мм × 150 мм класу А500С. Конструкція стенду для випробувань зображена на Рисунку 2.

Для забезпечення необхідної температури в камері стенда використовувався парогенератор, який дозволяв отримати пару температурою до $150{ }^{\circ} \mathrm{C}$ і тиск до 0,5 МПа. У разі необхідності, для більш точного забезпечення тиску в камері стенда тривалий час використовувався компресор.

\section{Виготовлення та підготовка експериментальних зразків і устаткування}

Для отримання достовірних експериментальних даних було виготовлено 3 зразки, які моделюють фрагмент захисної оболонки РВ енергоблока AЕС. Склад бетонної суміші був підібраний співробітниками відділу технології виготовлення залізобетонних конструкцій Державного підприємства «Державний науково-дослідний інститут будівель- них конструкцій». Склад бетону приблизно відповідає реальному складу бетону захисної оболонки PB енергоблока АЕС. Міцність бетону підбиралась відповідною міцності бетону, яка визначена за результатами випробовувань кернів, відібраних 3 тіла оболонки. Оскільки реальна міцність бетону значно перевищила проєктну M400 (клас бетону (25/30), для виготовлення експериментальних зразків був підібраний бетон міцністю M500 (B40 або (32/40). Паралельно з бетонуванням основних зразків були виготовлені куби і призми для контролю міцності бетону на стиск і модуля пружності. Оскільки з одного замісу бетонної суміші було неможливо виготовити всі моделі з кожної партії бетону було виготовлено по 12 зразків-кубів 100 мм $\times 100$ мм $\times 100$ мм і по 9 зразків-призм 100 мм $\times 100$ мм $\times 400$ мм. Зразки були випробувані на 28 добу твердіння в нормальних умовах. Також для кожної партії було виготовлено по 3 зразки-куби, які тверднули в тих же умовах, що і бетон основного зразка. Після витримування протягом 28 діб у камері нормального твердіння зразки були випробувані для визначення міцності бетону на стиск і модуля пружності.

Експериментальні зразки для випробувань були задокументовані та ідентифіковані із зазначенням вихідних даних для моделювання: характеристик бетону (бетонна суміш, параметри формування, тривалість існування, міцність під час стиснення, розтягнення і вигину, гранична розтяжність, модуль пружності, коефіцієнти Пуассона і температурнихдеформацій), арматуриіпараметрів натягу попередньо напруженої арматури;

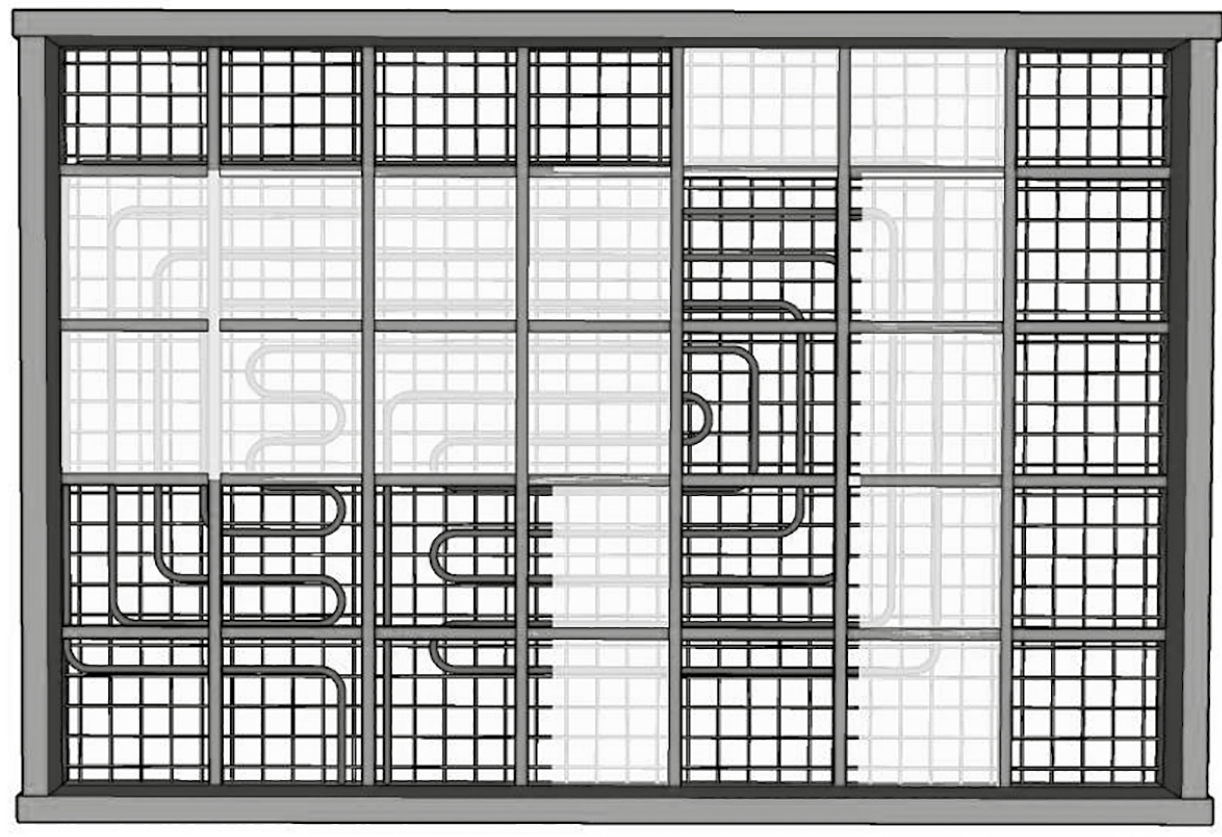

Рисунок 2 - Конструкція стенду для випробувань 
листів сталевого облицювання і прокату; геометричних характеристик зразків. У процесі підготовки до випробувань було виконано: обстеження поверхонь зразків 3 фіксацією пошкоджень; обмірні роботи зі встановлення фактичних геометричних параметрів зразків; підтяжку постнапружених стрижнів до зусилля 20 тм; перевірку герметичності зварних з'єднань листів (у разі виявлення негерметичних ділянок їх зачистка і повторне зварювання); затягування болтів стенда до величини, що забезпечує герметичність системи стенд-зразок за тиску пари 4 атм; перевірку герметичності стенда (у разі виявлення негерметичних ділянок додаткова герметизація); установлення стенда в проєктне положення; укладання стрічок ущільнювальної гуми і встановлення дослідного зразка зверху стенда; підключення до мережі електропрогрівання, подачі пари під тиском, системи відведення пари і води, термопар для виміру температури, манометра тиску в системі; розмітку місць установлення приладів для вимірювання деформацій металевої оболонки зразка, встановлення приладів і їх нумерація; перевірка працездатності всіх систем і приладів.
Вимірювання деформацій (переміщення листів) металевої оболонки зразка виконувалося механічними приладами з ціною ділення 0,001 мм.

Схема розміщення вимірювальних приладів для виміру деформацій наведена на Рисунку 3.

\section{Випробування зразків}

Конструкція випробувального устаткування дозволяла реалізувати умови режиму впливів температури та тиску, близького до реальних умов під час експлуатації та у процесі розвитку МПА (Рисунок 2). Під час випробувань виконувалися такі операції: розігрів сталевих листів і бетону стенда до температури $40{ }^{\circ} \mathrm{C}$, розігрів сталевих листів моделі до температури $100{ }^{\circ} \mathrm{C}$ при тиску 0,35 МПа; підтримка для листів ГСО температури $100{ }^{\circ} \mathrm{C}$ протягом 6 годин при тиску 0,15 МПа.

Динаміка проведення експерименту в часі виконувалась відповідно до програми (Рисунок 4).

На Рисунку 5 наведено загальний вигляд стенда в проєктному положенні перед випробуванням (Рисунок 5а) та дослідного зразка на стенді в процесі випробування (Рисунок 56).
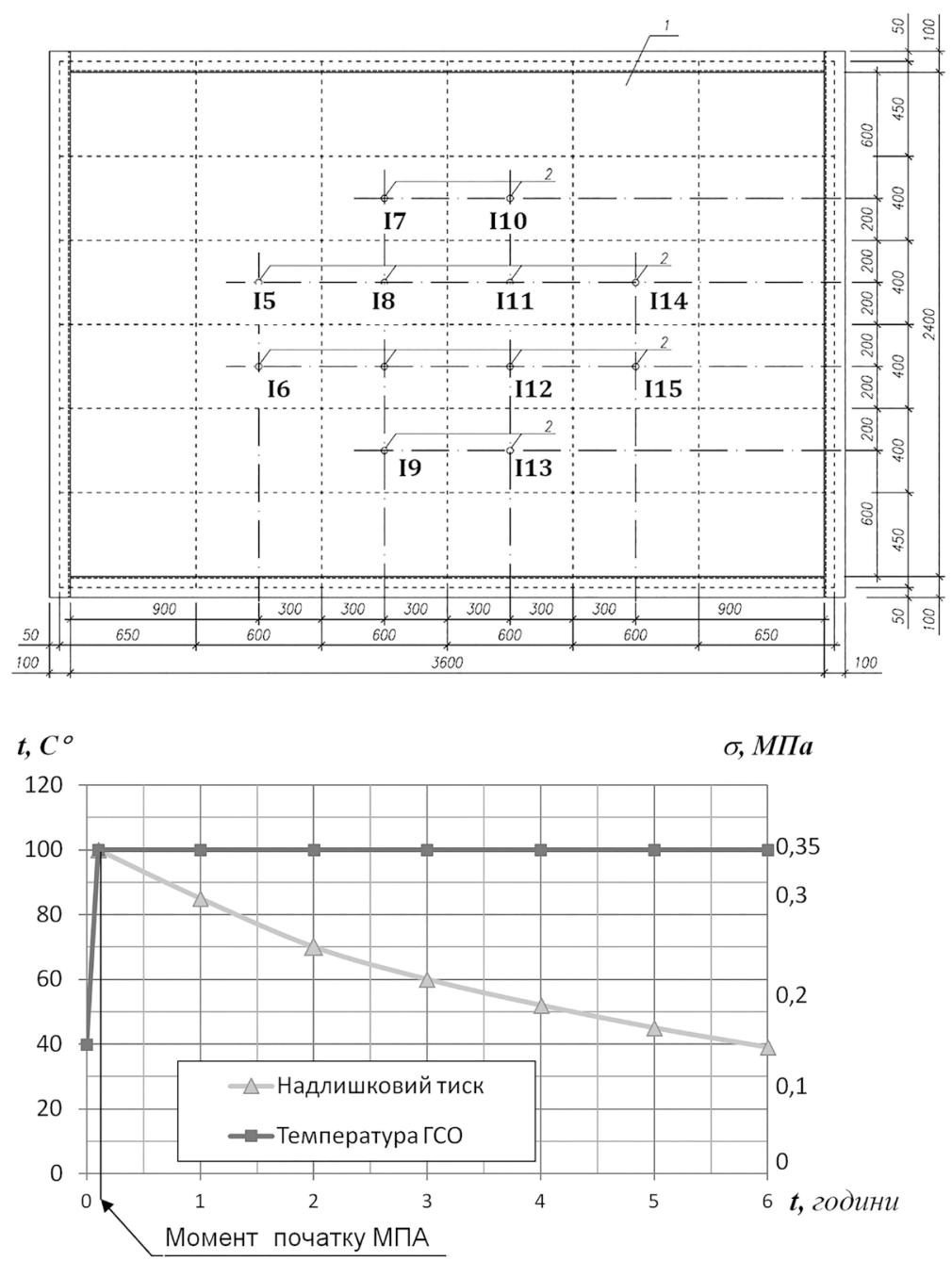

Примітки:

1 - дослідний зразок;

2 - трубки ПВХ $\varnothing 10$ мм

Рисунок 3 - Схема розташування вимірювальних приладів
Рисунок 4 - Графіки залежності впливу силових факторів в часі під час МПА 

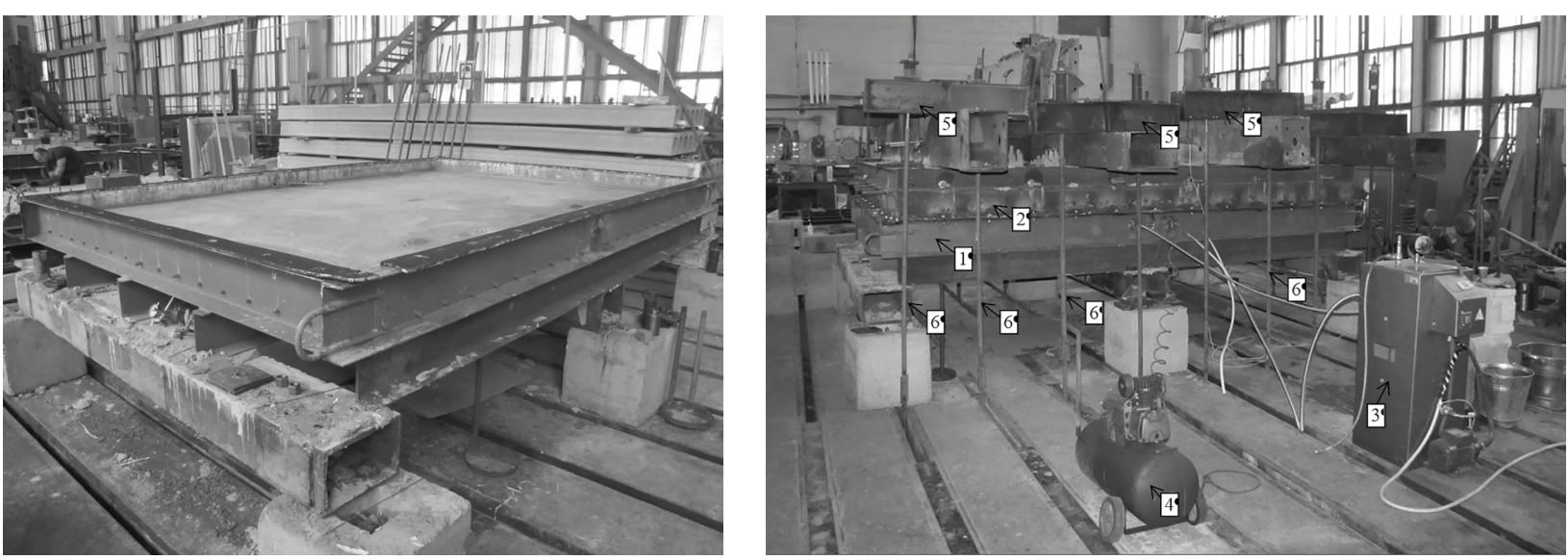

a)

б)

Примітки: 1 - стенд; 2 - дослідний зразок; 3 - парогенератор; 4 - компресор; 5 -траверси; 6 - тяжі

Рисунок 5 - Загальний вигляд стенда в проєктному положенні перед випробуванням (а) та дослідного зразка на стенді під час випробування (б)

\section{Результати випробування}

Під час випробувань контролювалися показники температури пари, внутрішньої і зовнішньої поверхонь зразків, показники вимірювальних приладів для визначення деформацій, стан поверхні зразків, герметичність з'єднань зразків зі стендом.
Показання вимірювальних приладів для визначення деформацій, які знаходились в центральній частині дослідного зразка № 1, і значення температури та тиску під час випробувань наведені в Таблиці 1.

Графіки розподілу температури бетону зразка у часі зображені на Рисунку 6. Як видно з Рисунка 6, розподіл температури в шарах бетону під час випробувань близький до теоретичного.

Таблиця 1 - Показники переміщення листа в центральній частині зразка № 1

\begin{tabular}{|c|c|c|c|c|c|c|c|c|c|}
\hline $\begin{array}{c}\text { Tиск, } \\
\text { МПа }\end{array}$ & 18 & 19 & 110 & 111 & 112 & 114 & $\mathrm{~T}_{1,}{ }^{\circ} \mathrm{C}$ & $\mathrm{T}_{2,}{ }^{\circ} \mathrm{C}$ & $\mathrm{T}_{3,}{ }^{\circ} \mathrm{C}$ \\
\hline 0 & 0,000 & 0,000 & 0,000 & 0,000 & 0,000 & 0,000 & 25 & 25 & 25 \\
\hline 0,12 & 0,001 & 0,016 & 0,034 & 0,004 & $-0,048$ & $-0,043$ & 29 & 60 & 68 \\
\hline 0,35 & 0,055 & 0,016 & 0,058 & 0,028 & 0,037 & 0,112 & 31 & 100 & 103 \\
\hline 0,25 & 0,053 & 0,016 & 0,098 & 0,042 & 0,084 & 0,114 & 35 & 100 & 105 \\
\hline 0,15 & 0,062 & 0,016 & 0,092 & 0,073 & 0,113 & 0,113 & 36 & 100 & 110 \\
\hline
\end{tabular}

Примітки: $\mathrm{T}_{1},{ }^{\circ} \mathrm{C}$ - температура зовнішньої бетонної поверхні; $\mathrm{T}_{2},{ }^{\circ} \mathrm{C}$ - температура ГСО; $\mathrm{T}_{3^{\prime}}{ }^{\circ} \mathrm{C}$ - температура в середині стенда

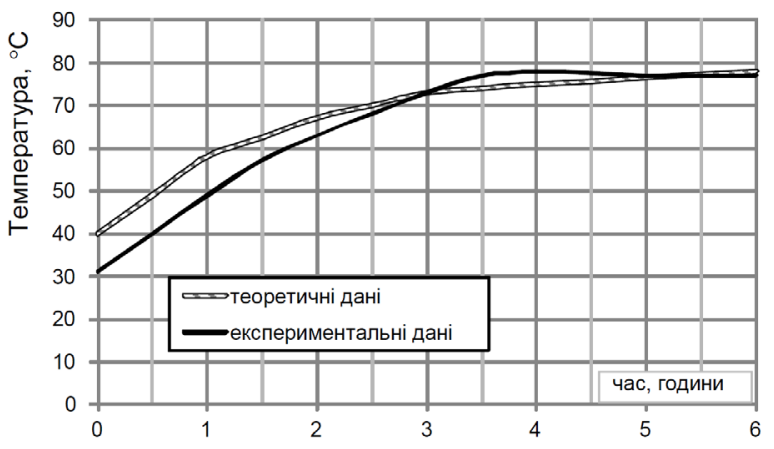

a)

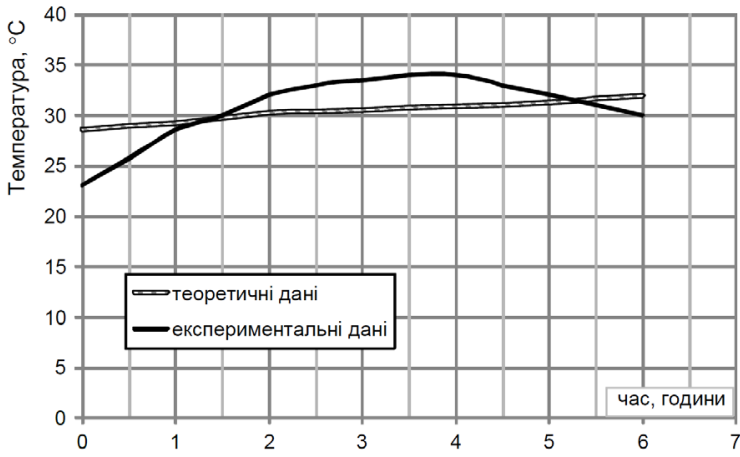

б)

Рисунок 6 - Розподіл температури зразка в часі для внутрішнього (а) та зовнішнього (б) шару бетона 


\section{Аналіз результатів експерименту}

Після проведення випробувань сталеві гермооблицювання зразків були оглянуті і встановлено, що вони не мають ознак руйнування, пошкоджень, поверхневих порушень суцільності металу відповідно до вимог СОУ НАЕК 014:2013 [6] та порушень зчеплення листів з бетоном і $\epsilon$ герметичними (повітронепроникними). Результати цих перевірок дозволяють зробити висновок, що порушення вказаних параметрів не було, за якісними показниками це свідчіть про те, що втрати стійкості не відбувалось [5].

Загальний вигляд дослідного зразка після проведення випробувань показано на Рисунку 7.

Оскільки виконати заміри переміщень безпосередньо на контакті металевого листа та бетону було неможливо, переміщення замірялись механічними приладами із зовнішньої поверхні зразка. В ідеалі, в Таблиці 1 повинні бути нулі, водночас у процесі випробовувань ми отримали деякі величини переміщень, поява цих показань зумовлена переміщеннями системи дослідного зразка, стенда та опор приладів під час зміни температури і тиску в системі. Причому, середнє значення заміряних переміщень панелей листа в центральній частині дослідного зразка становить 0,066 мм, що складає всього 0,000825 товщини листа.

Аналіз фундаментальних теоретичних досліджень щодо втрати стійкості систем, які деформуються [14], [15], показав, що переміщення такої незначної величини не може характеризувати втрату стійкості листа (мембрани). Насамперед, необхідно визначити, у якій стадії працює метал під час критичних температур. Оскільки під час МПА температура листа ГСО розігрівається до $100{ }^{\circ} \mathrm{C}$, то при коефіцієнті лінійного теплового розширення $\mathrm{a}=1 \times 10^{-5 \circ} \mathrm{C}$ деформації складатимуть величину $\varepsilon_{\mathrm{s}}=100 \times 10^{-5}$, що значно менше

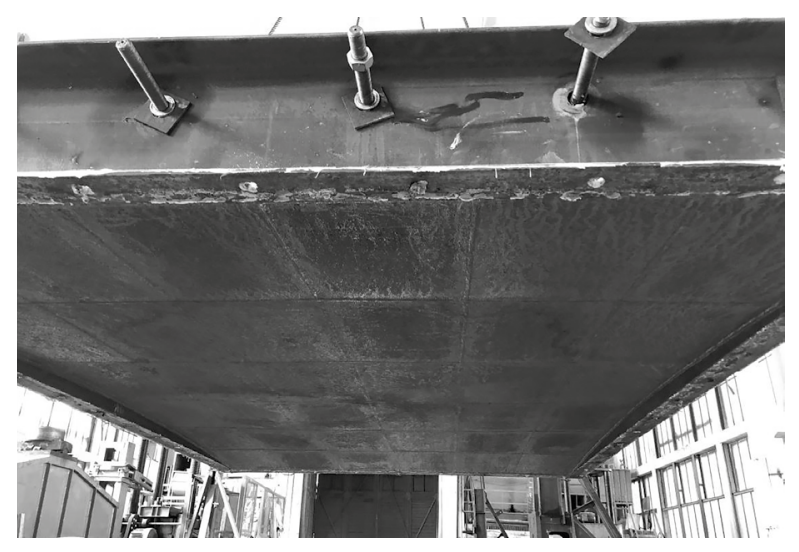

Рисунок 7 - Загальний вигляд дослідного зразка після випробувань критичних деформацій для цього класу сталі $\varepsilon_{\text {so }}=181 \times 10^{-5}$. Отже, матеріал листа працює в лінійній (пружній) стадії і можна використовувати закономірності втрати стійкості з [14], [15]. Якщо припустити, що втрата стійкості відбудеться для всього листа дослідного зразка, то переміщення повинні складати не менше двох величин підйому $\Delta=2 \mathrm{f}=2 \times 65=130$ мм (Рисунок 1). Як видно 3 Таблиці 1, переміщення листа експериментального зразка на три порядки менше. Тому втрати стійкості не відбулося.

Розглянемо можливість місцевої втрати стійкості листа між його розкріпленням до кутиків. Відповідно до технології монтажу ЗАО пластини розміром $600 \times 400 \times 8$ приварені до кутиків та зварені між собою. Кутики заанкерені в залізобетонній попередньо напруженій оболонці товщиною 1200 мм. Як було зазначено раніше, в науково-технічній літературі рішення втрати стійкості пластини під час нагріву зі співвідношенням b/a>66 не розглядалось. Тому зробимо оцінку можливості втрати стійкості пластини за консервативним підходом. Приймемо такі допущення:

за температури $100{ }^{\circ} \mathrm{C}$ тиск дорівнює атмосферному (не враховується активний тиск на ГСО);

закріплення пластини на кутики шарнірне;

відсутнє зчеплення металевих пластини з бетоном;

температура замикання системи дорівнює $0,0^{\circ} \mathrm{C}$ (будівельні норми рекомендують приймати $10,0^{\circ} \mathrm{C}$ );

деформації стиску від попереднього напруження канатів захисної оболонки відповідно до виконаних розрахунків складають орієнтовно $30 \times 10^{-5}$, що еквівалентно впливу температури приблизно $30,0^{\circ} \mathrm{C}$.

Вирізаємо ділянку шириною 400 мм і виконуємо розрахунок стійкості за рекомендаціями розділу 66 [13]. Величина критичної температури з урахуванням обтиску конструкції ЗАО складає:

$$
\begin{gathered}
\Delta t_{k r}^{\circ}=\frac{\pi^{2}}{\lambda^{2} \alpha}-30 \times 10^{-5}=145,46^{\circ} \mathrm{C}, \\
\text { де: } \lambda=\frac{l}{h}=\frac{600}{8}=75 ; \\
a-\text { коефіцієнт теплового розширення сталі } \\
1 \times 10^{-5} .
\end{gathered}
$$

Отже, у разі найбільш консервативних допущень величина критичної температури місцевої втрати стійкості значно перевищує діючу $\left(100{ }^{\circ} \mathrm{C}\right)$, тому вона малоймовірна. Якщо врахувати, що реальне металеве облицювання має зчеплення 3 бетоном і притискається мінімальним тиском у 0,15 МПа до бетону, то можна стверджувати, що втрата стійкості як на великій площі, так і на ділянках між закріпленням до кутиків не відбувається. Це і підтвердили експериментальні дослідження. 


\section{Висновки}

За результатами проведених випробувань дослідних зразків захисної оболонки енергоблоків встановлено таке:

аналіз значень переміщень підтвердив, що втрати стійкості сталевої оболонки дослідних зразків не відбулося;

руйнувань, пошкоджень, порушення герметичності дослідних зразків не зафіксовано.

\section{Список використаної літератури}

1. ПНАЭ Г-10-007-89. Нормы проектирования железобетонных сооружений локализующих систем безопасности атомных станций.

2. NEA/CSNI/R(2005)5. International Standard Problem No. 48. Containment Capacity. Synthesis Report. Organisation for Economic Co-operation and Development. Nuclear Energy Agency. Committee on the Safety of Nuclear Installations. 2005. Vol 1. $281 \mathrm{p}$.

3. ПМ.1.3812.0248. Рабочая программа исследований строительных конструкций защитной оболочки энергоблоков № 1, 2 ОП ЮУАЭС, 2016.

4. Научно-технический отчет «Экспериментальнотеоретические исследования строительных конструкций защитной оболочки энергоблоков №1,2 (В-302 и В-338) ОП ЮУАЭС». Договор № 5595 от 18.09.2017 г. Этап 2. Изготовление образцов, подготовка и наладка оборудования, проведение испытаний, анализ результатов и составление технического отчета. Научно-техническое сопровождение результатов работ и отчетной документации при ее рассмотрении и согласовании в ГИяРу. Книга 1. Выполнение экспериментальных исследований образцов, моделирующих фрагменты защитной оболочки (ЖОК с ГСО) на предмет сохранения целостности ГСО (в т. ч., сварных швов) при потере устойчивости под действием соответствующих силовых и температурных нагрузок при МПА+ПЗ.

5. Заключение по результатам испытания на воздухонепроницаемость трех фрагментов защитной оболочки ядерного реактора. НАК Украины. Институт электросварки им. Е. О. Патона. Опытное конструкторскотехнологическое бюро. Протокол испытания № 1-08/19. РТ.

6. СОУ НАЕК 014:2013. Техническое обслуживание и ремонт. Контроль неразрушающий капиллярный. Методика контроля основных материалов (полуфабрикатов), сварных соединений и наплавок оборудования и трубопроводов АЭУ. Затвердж. наказом ДП «НАЕК «Енергоатом» від 16.03.2016 № 254.

7. ДБН В.2.6-98:2009. Конструкції будинків і споруд. Бетонні та залізобетонні конструкції. Основні положення. Київ: ДП «Укрархбудінформ». 2011. 69 с. (Державні буд. норми України).
8. ДСТУ Б В.2.6-156:2010. Бетонні та залізобетонні конструкції з важкого бетону. Правила проектування. Київ: Мін регіонбуд України. 2011. 118 с.

9. ДСТУ-Н Б ЕN 1992-1-2:2012. Єврокод-2 Проектування залізобетонних конструкцій. Частина 1-2. Загальні положення. Розрахунок конструкцій на вогнестійкість (EN 1992-1-2:2004, IDT).

10. ДСТУ-Н Б ЕN 1992-1-1:2010. Єврокод 2. Проектування залізобетонних конструкцій. Частина 1-1. Загальні правила і правила для споруд (EN 1992-1-1:2004, IDT).

11. Бачинский В.Я. О потере устойчивости деформирования изгибаемого бруса. Республиканский межведомств. науч.-техн. сб. Строительные Конструкции. К.: Будівельник, 1982. Вип. 35.

12. Бамбура А.М. Про втрату стійкості позацентрово стиснутих елементів з пружно-пластичного матеріалу. Механіка і фізика руйнування буд. матер. та конструкцій: 36. наук. праць. Львів: Каменяр, 2002. Вип. 5. С. 213-218.

13. Биби Э.В., Нараянан Р.С. Руководство для проектировщиков к Еврокоду 2: Проектирование железобетонных конструкций: руководство для проектировщиков к EN 1992-1-1 и EN 1992-1-2. Еврокод 2: Проектирование железобетонных конструкций. Общие правила и правила для зданий. Противопожарное проектирование строительных конструкций: перевод с английского. М.: МГСУ, 2012. 292 с.

14. Вольмир А.С. Устойчивость деформируемых систем. Москва: Из-во «НАУКА», Главная редакция физикоматематической литературы, 1967. 984 с.

15. Пановко Я. Г., Губанова И.И. Устойчивость и колебания упругих систем. Современные концепции, парадоксы и ошибки. Москва: Из-во «НАУКА», Главная редакция физико-математической литературы, 1987. 352 с.

\section{References}

1. PNAE G-10-007-89. Norms of design of reinforced concrete structures of localizing safety systems for nuclear power plants.

2. Organization for Economic Co-operation and Development. Nuclear Energy Agency. Committee on the Safety of Nuclear Installations - NEA/CSNI/R. (2005). International Standard Problem №48 Containment Capacity. Synthesis Report. (2005)5/Vol1.

3. Work program for research of the civil structures of the $\mathrm{SE}$ «South-Ukraine NPP» power units 1 and 2 containment shell PM.1.3812.0248 (2016). Ukraine.

4. Scientific and technical report «Experimental and theoretical studies of the containment shell structures of power units 1 and 2 (V-302 and V-338) of SE «South-Ukraine NPP» Agreement No.5595 of 18.09.2017. Stage 2. Production of samples, preparation and adjustment of equipment, testing, the analysis and drawing up of technical report. Scientific and technical support of the results of work and reporting documentation during consideration and approval in GIYARU. Book 1. Performance of experimental research of samples 
modeling fragments of a protective cover (ZhOK with GSO) for preservation of FSO integrity (including, welds) at loss of stability under the influence of the corresponding power and temperature loadings at MPA + DE. (2019). Ukraine.

5. Conclusion on the results of air tightness testing of three fragments of the nuclear reactor containment. Test report № 1-08/19. RT. (2019). NAS of Ukraine. E. O. Paton Electric Welding Institute. Experimental design and technological bureau. Kyiv.

6. SOU NAEK 014:2013 Maintenance and repair. Nondestructive capillar testing. Control methods of basic materials (semi-finished products), welding joints and building-up of NPP equipment and pipelines.

7. Structures of buildings and facilities. Concrete and reinforced concrete structures with heavy weight structural concrete. General provisions. (2011) DBN V.2.6-98:2009. Kyiv: Minregionbud of Ukraine.

8. Structures of buildings and erections. Concrete and reinforced concrete structures with heavy weight structural concrete. Design rules. (2011). DSTU B B.2.6-156: 2010. Kyiv: Minregionbud of Ukraine.

9. Eurocode 2: Design of concrete structures - Part 1-2: General rules (2004) EN 1992-1-2:2004 (EN 1992-1-1:2004, IDT).

10. Eurocode 2: Design of concrete structures - Part 1-1: General rules and rules for buildings. (2010) DSTU-N B EN 19921-1:2010 (EN 1992-1-1:2004, IDT).

11. Bachinskiy V. (1982). On loss of stability of deformation of bent beam. Republic interagency scientific and technical collected papers «Civil structures», 35. Kyiv: Budivelnik.

12. Bambura A. (2002). Concerning buckling of the eccentric-compressed elements from an elasto-plastic material. Mechanics and physics of destruction of construction materials and structures. Scientific collected papers, 5. Lviv: Kamenyar.

13. Bibi E., Narayan R. (2012). Guidance of Eurocode-2 for designers: Design of reinforced concrete structures. Translation from English. Moscow: PhGBOU VPO «VGSU: Eurocodes»

14. Volmir A. (1967). Stability of deformable systems. Moscow: Nauka.

15. Panovko Ya., Gubanova I. (1987). Stability and fluctuations of elastic systems. Current concepts, antimonies and mistakes. Moscow: Nauka.

\section{Experimental Study of Fragment of Prestressed Containment of Nuclear Power Plant Unit}

\author{
Bambura A. ', Sazonova I.', Karpenko A.', \\ Zharko L.', Fesenko O.', Iniushev V. ${ }^{2}$, \\ Zhygalov I. ${ }^{2}$, Posokh V.
}

\author{
${ }^{1}$ State Enterprise «The State Research Institute \\ of Building Constructions», Kyiv, Ukraine \\ ${ }^{2}$ State Enterprise «State Scientific Engineering \\ Center for Control System and Emergency \\ Response», Kyiv, Ukraine
}

Containment is a protective element of the reactor plant that isolates it from the environment and ensures the localization of radioactive substances in the subcontainment space in design basis accident. To ensure the tightness of the reactor compartment along the inner reinforced concrete surface of containment, there is an $8 \mathrm{~mm}$ thick envelope steel wall (ESW). In accordance with current construction regulations, ESW should be checked for loss of stability when calculating the structure of containment. Testing the ESW elements for stability loss by the method described in the current regulation, PNAE G-10007-89, has showed stability loss of ESW elements in maximum design basis accident (MDBA) what makes it impossible to extend the life of the reactor. To study this issue, a program of experimental studies was drawn up in order to maintain ESW integrity including integrity of welding joints in case of possible stability loss due to applied forces and thermal actions. The purpose of experimental study was to research the stress-strain state of physically and geometrically sound models of the containment of nuclear power plants in order to maintain ESW integrity including integrity of welding joints in case of stability loss under the influence of loads arising in maximum design basis accident. In preparing the experimental study engineering solutions were developed for test samples, models, and test equipment. The results from inspection of technical condition of containment and data on the real strength and composition of concrete were used in the development of test samples. According to the results of the survey of three test samples, it was found no stability loss of steel envelope of test samples thus no failure, damage, or leakage of the test samples were recorded.

Keywords: Containment, technical condition, envelope steel wall, stability loss, test samples, rig, design basis accident. 